\title{
University Lecturers' Conceptions of Ethics and Citizenship Education in the European Higher Education Area: a Case Study
} \author{
and Maria Rosa Buxarrais Estrada ${ }^{3}$ \\ 1. University of Barcelona (UB), Spain | franciscoesteban@ub.edu \\ 2. ESADE, Spain | teodor.mellen@esade.edu \\ 3. University of Barcelona (UB), Spain | mrbuxarrais@ub.edu
}

Francisco Esteban Bara', Teodor Mellen Vinagre ${ }^{2}$

Submitted in: February 2013 Accepted in: February 2014 Published in: July 2014

\section{Recommended citation}

Esteban, F., Mellen, T. \& Buxarrais, M.R. (2014). University Lecturers' Conceptions of Ethics and Citizenship Education in the European Higher Education Area: a Case Study. RUSC. Universities and Knowledge Society Journal, 11(3). pp. 22-31. doi http://dx.doi.org/10.7238/rusc.v11 i3.1778

\begin{abstract}
Ethics and Citizenship education has become the focus of considerable debate since the launch of the European Higher Education Area. That this is the case is interesting, as it is a type of education that forms part of the educational mission of universities, as its history plainly demonstrates. Ethics and Citizenship education cannot be analysed solely in terms of its pedagogical requirements, the skills and competencies that it seeks to develop, or the type of students and professionals that the world needs today. Its success also requires that we explore what university lecturers understand by this type of education, the context it currently finds itself in, and how students perceive such an education. This paper presents a case study conducted on university lecturers in Education, Philosophy and Humanities at several European institutions.
\end{abstract}

\section{Keywords}

European Higher Education Area; ethics; citizenship

\section{Concepciones del profesorado universitario sobre la formación ética y ciudadana en el Espacio Europeo de Educación Superior: un estudio de caso}

\begin{abstract}
Resumen
La formación ética y para la ciudadanía está siendo objeto de debate desde la implantación del espacio europeo de educación superior. Resulta interesante que así sea, pues se trata de un tipo de formación que forma parte de la misión formativa de la universidad, tal y como su historia se ha encargado de demostrarnos. Este tipo de formación no puede ser analizada sólo desde la pedagogía que requiere, las competencias que se deben fomentar o el tipo de estudiantes y profesionales que la contemporaneidad necesita. Su buen desarrollo también necesita adentrarse en qué entiende el profesor universitario por dicha formación, en qué estado cree que se encuentra y cómo concibe a sus estudiantes al respecto. Este trabajo presenta el estudio del caso de profesores de diferentes universidades europeas de las áreas de educación, filosofía y humanidades.
\end{abstract}

\section{Palabras clave}

Espacio Europeo de Educación Superior; ética; ciudadanía

RUSC VOL. 11 No 3 | Universitat Oberta de Catalunya and University of New England | Barcelona, July 2014

@) Francisco Esteban, Teodor Mellen and Maria Rosa Buxarrais | @ FUOC, 2014 | University Lecturers'Conceptions of Ethics and Citizenship Education... 


\section{Introduction}

The launch of the European Higher Education Area (EHEA) can be regarded as the reconstruction of new European universities for the new century (European University Association, 2005, 2010). Universities are multi-faceted institutions, and one of the many aspects affected by the above is university education (European Council, 1996; European Commission, 2006). In the current setting, university education is conceived of in terms of competencies (European Council, 2007). In addition, as several important studies have shown, there is a diversity of competencies, among which we find those pertaining to ethics, morality and citizenship (González \& Wagenaar, 2003). Ethics and Citizenship education in universities has become a matter of concern, even in areas of politics and university management (European Commission, 1995; OECD, 1997).

There are many ways to analyse this issue, but we are interested in approaching it from the angle of what university lecturers think about this kind of education. The reason for that is because we believe that university lecturers' thinking has a considerable bearing on what subsequently occurs when lecturers and students come together. Pedagogical thinking informs educational practice. The aim of this work is to present some data in this respect, which illustrate what university lecturers in Education, Philosophy and Humanities at several European institutions think about some of the aspects of Ethics and Citizenship education in universities.

\section{Theoretical framework: Ethics and Citizenship education in universities}

Ethics and Citizenship education forms part of the very notion of higher education. In addition, it is the kind of education that has existed since the universitas were first founded across Europe in the High Middle Ages (Rüegg, 1992). Classic reference works (Newman, 1852; Ortega \& Gasset, 1930; Wyatt, 1990) and more recent works on the idea and mission of universities (Pelikan, 1992; Kerr, 2001; Scott, 2006) refer to such education in one way or another.

This is testimony to the fact that it is a substantial and not a superficial issue. However, there are various angles of approach to Ethics and Citizenship education. Different versions of such education have been developed for different reasons. When implemented, these versions shape it one way or another. We have roughly divided these different versions into three categories.

\subsection{Three versions of Ethics and Citizenship education in universities}

The first version we want to refer to is the one that considers that Ethics and Citizenship education has no place in universities:

"College and university teachers can (legitimately) do two things: (1) introduce students to bodies of knowledge [and]

(2) equip those same students with the analytical skills... that will enable them to move confidently... That's all there is

to it, nothing more, nothing less." (Stanley, 2008, p. 6).

There are several reasons supporting this version. University education is identified with professional, technical and scientific education. That is the focus of its attention, and thus there is no place for any other type of education in universities. It is surprising to find that the opposite was the case in the very first universities, where a speculative 
kind of education oriented towards professional practice did not form part of the curricula of university education, which was wholly focused on intellectuality and the search for truth (verum), good (bonum) and beauty (pulchrum) (Rüegg, 1992; Berube, 2007). However, when the first universities were founded, formalised mass education systems did not exist. These emerged in the mid 19th century in several European countries and the United States, and they took responsibility for the Ethics and Citizenship education of the new generations. Thus, universities divest themselves of one of the functions that gave them meaning. In addition, the defenders of this version not unjustifiably point out that the line separating Ethics and Citizenship education and indoctrination is too fine. Authors like Derek Bok (Bok, 2007) warn of the dangers entailed by thoughts like those of Henry Giroux, which encourage critical pedagogy (Giroux, 2007).

This is a version that, while it cannot be overlooked, has weaknesses. Among others, there is no guarantee that Ethics and Citizenship education will have been completed at the educational level prior to higher education. Perhaps now more than ever, and owing to the individualism (Giddens, 1991; Beck, 1992) and disaffection towards social and political institutions that quite a few young people are displaying (Forbrig, 2005; Saha, Print \& Edwards, 2007; Duke, 2008), we need European universities that opt to educate professional young people who take responsibility for reality from an Ethics and Citizenship perspective (Steiner, 2004).

The second version is the one that considers Ethics and Citizenship education as an education in the major Ethics and Citizenship issues that we face today. In this respect, university students should acquire the highest level of moral reasoning development (Kohlberg, 1981, 1984). Topics such as justice, equity, sustainability, gender equality or multicultural coexistence are particular to this way of conceiving of Ethics and Citizenship education. At the present time, it is hard to find a university that incorporates such issues in its mission statement.

However, this may be an incomplete version of Ethics and Citizenship education. Today's reality shows that while most students take on board the fact that a certain level Ethics and Citizenship is expected of them, they do not always rise to it (Procario-Foley \& Bean, 2002; Moore, 2008).

The third version is the one that considers Ethics and Citizenship education as an education of an ethical nature (Lapsley \& Clark, 2005; Nucci \& Narváez, 2008; Doris, 2008) and, therefore, it is focused on implementing a series of moral habits and certain ethical virtues. As Michael Sandel suggests, universities:

"... can't entirely dispense with the idea that their role is not only to advance certain ends but also to honor and reward certain virtues." (Sandel, 2011, p. 206).

It is clear that virtue can be understood in a Homeric, Aristotelian, Thomist or Christian sense, or in accordance with Franklin's contribution. Alasdair Maclntyre combines these three variants of virtue and defines virtue as:

"... an acquired human quality the possession and exercise of which tends to enable us to achieve those goods which are internal to practices and the lack of which effectively prevents us from achieving any such goods." (Maclntyre, 1984, pp. 270-271)

In this case, Ethics and Citizenship education in universities can be regarded as the conquest of certain virtues, which undoubtedly form part of a competent conduct. Intellectual rigour, an appreciation of authorised voices, admiration for the best of what is said or respect towards forms would be among them (Pérez-Díaz, 2010). 


\section{Study}

The study presented here is part of a research project whose aim is to find out what university lecturers in Education, Philosophy and Humanities think about Ethics and Citizenship education in universities. A total of 89 lecturers took part in the study. Of these, 33.7\% were male and 66.3\% female; 74.2\% lectured in Education, 19.1\% in Humanities and $6.7 \%$ in Philosophy; $49.4 \%$ had fewer than 15 years of university teaching experience and $50.6 \%$ had 15 or more years of experience. The lecturers were from 6 universities in 4 European countries, distributed as shown in the following table:

Table 1. Lecturers participating in the study, by university

\begin{tabular}{|l|c|c|}
\hline \multicolumn{1}{|c|}{ University } & Total & (\%) \\
\hline SEU & 59 & 66.3 \\
\hline University of Barcelona (UB), Spain & 30 & 33.7 \\
\hline University of Lisbon (ULisboa), Portugal & 12 & 13.5 \\
\hline University of Minho (UMinho), Portugal & 9 & 10.1 \\
\hline University of Trás-OS-Montes and Alto Douro (UTAD), Portugal & 8 & 9.0 \\
\hline NEU & 30 & 33.7 \\
\hline University of Humanities, Netherlands & 21 & 23.6 \\
\hline University of Helsinki, Finland & 9 & 10.1 \\
\hline Total & 89 & 100.0 \\
\hline
\end{tabular}

Two groups were formed according to the area or context in which the lecturers' universities were located. The University of Barcelona (UB), Spain, the University of Trás-os-Montes and Alto Douro (UTAD), Vila Real, Portugal, the University of Lisbon (ULisboa), Portugal, and the University of Minho (UMinho), Braga, Portugal, formed the group of universities in Southern Europe (SEU) (66.3\%), while the University of Humanities, Utrecht, Netherlands, and the University of Helsinki, Finland, formed the group of universities in Northern Europe (NEU) (33.7\%). From a methodological viewpoint, this grouping on the one hand served to combine the opinions of university lecturers from similar contexts with respect to Ethics and Citizenship education in universities, and on the other to increase the significance and statistical validity of the results.

The data collection instrument used was an online self-administered questionnaire survey of a random selection from the sample of aforementioned universities, which included open and closed (Likert-scale) questions. The results presented further below correspond to the answers obtained for items 2, 3, 4, 5 and 7, that is to say: What role, if any, do lecturers give to the university's educational mission from the viewpoint of Ethics and Citizenship? (2); How do you think your students conceive of universities in general and of this type of education in particular? (5); Do you think that the university you work for promotes such education and, if so, to what extent and how? (3); What difficulties do you come up against when fostering such education? (4); and finally, How do you accomplish it? (7).

In the data presented below, and specifically in those comparing NEU to SEU, aspects of gender and teaching experience, one $\left({ }^{*}\right)$, two $\left(^{* *}\right)$ or three $\left(^{* *}\right)$ asterisks appear after the central values indicating statistical significance at $0.05,0.01$ and 0.001 , respectively. These calculations were done using PASW Statistics 18.0 software. 


\section{Results}

On the issue of whether universities should provide their students with an Ethics and Citizenship education, the vast majority of lecturers felt that they should (94.4\%). Of these, and more specifically, a vast majority felt that the missions of universities were to educate students in an integral manner (97.6\%), to convey the codes of ethics of each profession (92.9\%) and to contribute to the construction of a fairer society (95.2\%). Regarding the latter of these three acceptations, we found significant differences between SEU $\left(98.2 \%^{* *}\right)$ and NEU $\left(89.7 \% \%^{* *}\right)$. The surveyed lecturers' conceptions of this variable did not vary when taking gender into account. However, some differences were found when taking teaching experience into account: $97.7 \% *$ of those lecturers with 15 years or more of teaching experience felt that a university education should include learning about professional codes of ethics, compared to $87.8 \% *$ of their colleagues with fewer than 15 years of teaching experience.

On the issue of what expectations the lecturers considered that their students had of a university education, it is worth noting that the vast majority of them felt that their students conceived of universities as places where they could get a professional qualification (92.1\%) or where they could acquire high-level scientific and cultural knowledge (82.0\%), rather than as institutions with a social dimension or commitment to the communities to which they belonged (42.7\%) or as institutions that would educate them from the viewpoint of Ethics and Citizenship (34.8\%). This instrumental or utilitarian conception of universities that, according to the lecturers, the students held did not show any noteworthy differences by gender apart from in the latter of the acceptations, which male lecturers $(50 \% *$ ) rated more than their female colleagues $(27.1 \% *)$. Elsewhere, more lecturers with fewer than 15 years of experience $\left(54.5 \%^{*}\right)$ felt that their students conceived of universities as institutions with a social dimension and commitment to the communities to which they belonged than those with 15 or more years of experience $\left(31.1 \%{ }^{*}\right)$.

However, and on the issue in hand, the most significant differences were found between SEU and NEU lecturers. Thus, only $18.6 \%{ }^{* * *}$ of SEU lecturers felt that their students were aware of the fact that they would be educated from the viewpoint of Ethics and Citizenship, whereas the figure was 3.5 times higher (66.7\%***) for NEU lecturers. Elsewhere, once again to a greater extent than their SEU colleagues (35.6\%*), NEU lecturers (57.6\%*) felt that their students conceived of universities as institutions with a social dimension and commitment to the communities to which they belonged.

Table 2. Some of the items stated by SEU and NEU universities (level of agreement) (\%)

\begin{tabular}{|c|c|c|c|c|}
\hline & Mean & $\begin{array}{l}\text { Uni } \\
\text { SEU }\end{array}$ & $\begin{array}{l}\text { type } \\
\text { NEU }\end{array}$ & p value \\
\hline Universities should provide their student with an Ethics and Citizenship education. & 95.2 & 98.2 & 89.7 & 0.081 \\
\hline $\begin{array}{l}\text { For students, universities are institutions that will educate them from the viewpoint of } \\
\text { Ethics and Citizenship. }\end{array}$ & 34.8 & 18.6 & 66.7 & 0.000 \\
\hline $\begin{array}{l}\text { For students, universities are institutions with a social dimension and/or commitment to } \\
\text { the communities to which they belong. }\end{array}$ & 42.7 & 35.6 & 56.7 & 0.049 \\
\hline $\begin{array}{l}\text { Ethics and Citizenship education is included in the mission statement as an objective to } \\
\text { be met. }\end{array}$ & 49.4 & 35.6 & 76.7 & 0.001 \\
\hline $\begin{array}{l}\text { Ethics and Citizenship education is incorporated as a competency into the official } \\
\text { curricula of degrees. }\end{array}$ & 51.7 & 40.3 & 73.3 & 0.014 \\
\hline
\end{tabular}

RUSC VOL. 11 No 3 | Universitat Oberta de Catalunya and University of New England | Barcelona, July 2014 
On the issue of whether universities really promote the students' Ethics and Citizenship education, significant differences were found between NEU and SEU lecturers. Thus, only 35.6\%** of SEU university lecturers acknowledged that Ethics and Citizenship education was one of their respective university institutions'missions and that it appeared in their mission statements, while $76.6 \%^{* *}$ of NEU lecturers acknowledged that this was the case. Regarding institutional acknowledgement, we found another difference when asking the question about the incorporation of competencies specific to Ethics and Citizenship education in official curricula. In this instance, $73.3 \%{ }^{* *}$ of NEU lecturers stated that they were in the curricula, while $40.7 \% \%^{* *}$ of SEU lecturers stated that they were.

In addition, 39.0\%* SEU lecturers felt that it was an issue that was discussed but not put into practice, while 20.0\%* of NEU lecturers felt the same. Moreover, 39.0\%*** of SEU lecturers felt that it was a personal and controversial issue, and that it was difficult to reach agreements on the type of Ethics and Citizenship education that should be fostered, while only 6.7\%*** of NEU lecturers felt the same. Finally, SEU lecturers $\left(54.2 \% \%^{* * *}\right.$, compared to $10.0 \%{ }^{* * *}$ of NEU lecturers) were also those who most felt that, in universities, Ethics and Citizenship education was not given the importance that it deserved because there were no academic consequences for either the lecturers or the students.

Table 3. Difficulties of developing Ethics and Citizenship education among students (level of agreement)

\begin{tabular}{|c|c|c|c|c|}
\hline & \multirow{2}{*}{ Mean } & \multicolumn{2}{|c|}{ University type } & \multirow{2}{*}{ p value } \\
\hline & & SEU & NEU & \\
\hline It is an issue that is discussed but not put into practice. & 32.6 & 39.0 & 20.0 & 0.049 \\
\hline It is a personal and controversial issue. & 28.1 & 39.0 & 6.7 & 0.001 \\
\hline It is an issue that is difficult to assess. & 59.6 & 64.4 & 50.0 & 0.271 \\
\hline It is an issue that has no academic consequences. & 39.3 & 54.2 & 10.0 & 0.000 \\
\hline
\end{tabular}

It is also worth noting the differences between NEU and SEU when it came to rating whether Ethics and Citizenship education fostered a climate of university life that went beyond purely academic matters: more than half of NEU lecturers $(53.3 \% *)$ felt that it did, while slightly more than one third of SEU lecturers $\left(35.6 \%{ }^{*}\right)$ felt the same.

On the issue of acknowledging the difficulties when it came to developing the students' Ethics and Citizenship education, significant differences were also found between NEU and SEU. For instance, 39.0\%*** of SEU lecturers felt that it was a personal issue on which it was difficult to reach specific agreements, while only $6.7 \%^{* * *}$ of NEU lecturers felt the same. Moreover, 54.2\%*** of SEU lecturers felt that it did not have any academic consequences, while only $10.0 \%^{* * *}$ of NEU lecturers felt the same.

Regarding the approach that the lecturers take towards Ethics and Citizenship education with their students, we found that there was a certain degree of engagement on some aspects. A high percentage of the lecturers surveyed (61.9\%) stated that they incorporated Ethics and Citizenship competencies into their teaching programmes, and that they also included content of this type (67.9\%). Similarly, a considerable percentage stated that they strengthened this type of education (65.5\%) either through dialogue (90.5\%), incorporating and addressing different viewpoints on Ethics and Citizenship issues (84.5\%), through the promotion of virtues such as effort, participation and punctuality (65.5\%), or sharing their own viewpoints with the students from an Ethics and Citizenship perspective (58.3\%). In addition, more lecturers with 15 or more years of experience admitted to promoting dialogue in their classrooms 
$\left(97.7 \%^{*}\right)$ and to taking into account the different ethical and moral stances that emerged (88.4\%*). Nevertheless, despite the above, SEU lecturers (74.5\%*) scored more highly than their NEU colleagues (48.3\%*) when it came to promoting the implementation of ethical virtues such as effort, respect, punctuality, participation, etc.

In general, however, the scores decreased considerably when they were asked whether they assessed their students' knowledge of this content (36.9\%), Ethics and Citizenship skills (36.9\%) and attitudes towards Ethics and Citizenship (34.5\%). On this aspect, the greatest differences between the lecturers were found to depend on their years of teaching experience. Thus, those lecturers with fewer than 15 years of experience acknowledged that they had fewer difficulties assessing their students' knowledge $\left(39.0 \%^{* *}\right)$ and skills $\left(46.3 \% \%^{* *}\right)$ relating to Ethics and Citizenship education.

\section{Conclusions}

The data presented above enabled us to draw several conclusions that are worth taking into account. The first is connected with the fact that a university education was mostly considered to be an Ethics and Citizenship education too. The fact that the sample belonged to knowledge areas with a close relationship to the issue of Ethics and Citizenship may have had a bearing on the results. Nevertheless, it is interesting to note that we did not find any representation of the first of the versions set out in the theoretical framework.

The second conclusion is connected with the conception of Ethics and Citizenship education that the lecturers attributed to their students. Although the lecturers felt that their students valued such an education in its various acceptations, the majority of them believed that these students conceived of universities mainly as places where they could get a professional qualification. We believe that this is something that could spread to and even become more acute in other knowledge areas that are not as vocational as those studied here. In short, the lecturers took the utilitarian and mercantilist view of universities held by their own students.

Regarding the third conclusion on the acknowledgment and promotion of an Ethics and Citizenship education by universities themselves, significant differences were found between NEU and SEU. NEU lecturers felt that their universities were more involved in the issue than their SEU colleagues did. This consideration went from the inclusion of such an education in the universities' official mission statements to its incorporation into official curricula. The Southern and Northern European universities differed considerably in this respect, and it would be a good idea to find out why, as the consequences are very important indeed. Regarding the second version of Ethics and Citizenship education, and as we pointed out in the theoretical framework, it is not enough to proclaim or set down intentions in official and academic documents. What is more, if the intentions are not implemented, they may no longer be considered as such, thus resulting in the issue being conceived as superficial, as several SEU lecturers indicated.

Continuing along the lines of the above, we have drawn a fourth conclusion. SEU lecturers also came across as being more pessimistic when it came to developing an Ethics and Citizenship education with their students. Their perception of the potential obstacles to the implementation of such an education was more negative than that of their NEU colleagues. On this point, it is worth recalling that, to a greater extent than their SEU colleagues, NEU lecturers conceived of their students as people who expected this type of education and therefore the difficulties involved in implementing it were easier to overcome or tended to diminish. Also on this point, it is surprising to find that SEU lecturers scored more highly than their NEU colleagues when it came to promoting the implementation of

RUSC VOL. 11 No 3 | Universitat Oberta de Catalunya and University of New England | Barcelona, July 2014

@ Francisco Esteban, Teodor Mellen and Maria Rosa Buxarrais | @ FUOC, 2014 | University Lecturers' Conceptions of Ethics and Citizenship Education. 
virtues such as effort, respect, punctuality, participation, etc. This finding, which tends to contradict what has been noted thus far, led us to the conclusion that NEU students do not need the promotion of these virtues as much as their SEU fellow students do. In addition, this finding confirms what was noted in the results in relation to the link between Ethics and Citizenship education and university life particular to NEU.

The fifth and last but not least conclusion is that the assessment of Ethics and Citizenship education appears to be an Achilles' heel for the lecturers. The majority of the lecturers stated that they did not assess it, perhaps owing to a lack of training, the difficulty in locating evidence or its negligible academic weight. However, a type of education that lacks assessment is, at the very least, an incomplete education, as we endeavoured to argue in the third of the versions set out in the theoretical framework. We consider that as research on the assessment instruments of Ethics and Citizenship education progresses and, above all, its results have academic consequences, the issue will gain the importance it deserves.

In short, the lecturers surveyed in this study, who formed part of several universities in the EHEA, held some opinions that were significantly different and others that were shared when it came to conceiving of Ethics and Citizenship education. The most important shared opinion was that it is an education that forms part of the educational mission of universities and, consequently, that it should be given the attention it deserves. In addition, whether in NEU or SEU, they were all trying, to a lesser or greater extent, to implement it with their students. Moreover, the matter of assessing such education and the problems it entails also appeared to be a shared issue. It is important to take all of this into account if the aim is to create a true EHEA, which is more than the juxtaposition of different institutions and university systems. However, unlike SEU lecturers, NEU lecturers felt better supported by their institutions and more optimistic about what their students expected from universities. As noted, this resulted in the implementation of Ethics and Citizenship education. This reality particular to NEU universities favours a combination of the second and third versions set out in the theoretical framework, a reality that, in our view, should be considered by SEU universities in order to endow 21st-century Europe with the EHEA that it needs.

\section{References}

Beck, U. (1992). Risk Society. Towards a New Modernity: Theory, culture and society. London: Sage.

Bentham, J. (1996). Introduction to the Principles of Morals and Legislation. Oxford: Oxford University Press.

Berube, M. (2007). What's Liberal about the Liberal Arts? New York: W. W. Norton.

Bok, D. (1986). Higher Learning. Cambridge: Harvard University Press.

Bok, D. (2007). Our Underachieving Colleges. New Jersey: Princeton University Press.

Duke, C. (2008). University Engagement: Avoidable Confusion and Inescapable Contradiction, Higher Education Management and Policy, 20, 1-11.

European Commission (1995). White paper on Education and Training. Teaching and Learning: Towards the Learning Society. COM (95) 590. Brussels: European Commission.

European Commission (2006, 5 September). Implementing the Community Lisbon Programme. Proposal for a Recommendations of the European parliament and the Council on the establishment of the European Qualifications Framework for lifelong learning, COM, 479 final.

European Council (1996). White Paper: Conclusions on the "Teaching and Learning: Towards the Learning Society", 3 (96/C, 195/01, in OJEC 6.VII.1996).

RUSC VOL. 11 No 3 | Universitat Oberta de Catalunya and University of New England | Barcelona, July 2014

(a) Francisco Esteban, Teodor Mellen and Maria Rosa Buxarrais | @ FUOC, 2014 | University Lecturers' Conceptions of Ethics and Citizenship Education. 
European Council (2007).On the new skills for new jobs. Official Journal of the European Union. 2007/C 290/01. Brussels: European Commission. Retrieved from http://www.eurlex.europa.eu/LexUriServ/LexUriServ.do?uri=0 J:C:2007:290:0001:0003:EN:PDF.

European University Association (2005). Trends IV: European Universities Implementing Bologna, S. Reichter \& C. Tauch. Brussels: EUA. Retrieved from http://www.eua.be/publications/.

European University Association, 2010. Trends VI: A decade of change in European Higher Education Area, A. Sursock \& H. Smidt. Brussels: EUA. Retrieved from http://www.eua.be/publications/.

Forbrig, J. (Ed.) (2005). Revisiting youth political participation. Strasbourg: Council of Europe Publishing.

Giddens, A. (1991). Modernity and Self-Identity: Self and Society in the Late Modern Age. London: Polity.

Giroux, H. (2007). Academic repression in the first person. The advocate, February, 1

González, J., \& Wagenaar, R. (Eds.) (2003). Tuning Educational Structures in Europe. Final Report. Phase One. Bilbao: Universidad de Deusto.

Kerr, C. (2001). The uses of the University. Cambridge: Harvard University Press.

Kohlberg, L. (1981). The Meaning and Measurement of Moral Development. Worcester, MA: Clark University Press. Kohlberg, L. (1984). Essays on Moral Development. The Psychology Moral Development. San Francisco: Jossey Bass. Lapsley, D., \& Clark, F. (2005). Character Psychology and Character Education. Indiana: University of Notre Dame Press. Macintyre, A. (1984). Tras la virtud. Barcelona: Editorial Crítica.

Moore, S. (2008). Practical approaches to ethics for Colleges and Universities. New Directions for Higher Education, 142. Newman, J. H. (1852). The idea of a university. New York: Longmans Green \& Co, 1927.

Nucci, L., \& Narváez, D. (2008). Handbook of Moral and Character Education. New York: Routledge.

OECD (1997). DeSeCo Project. Definition and Selection of Competencies: Theoretical and Conceptual Foundations. Paris: OECD.

Ortega y Gasset, J. (1930). La misión de la universidad. Madrid: Alianza Editorial.

Pelikan, J. (1992). The idea of the University: a Re-examination. New Haven: Yale University Press.

Pérez-Díaz, V. (2010). Universidad, Ciudadanos y nómadas. Oviedo: Ediciones Nobel.

Procario Foley, E., \& Bean, D. (2002). Institutions of Higher Education: Cornerstones in Building Ethical Organizations,

Teaching Business Ethics, 6, 101-116. doi http://dx.doi.org/10.1023/A:1014214909390

Rüegg, W. (1992). A history of the University in Europe. Cambridge: Cambridge University Press.

Saha, J. L., Print, M., \& Edwards, K. (Eds.) (2007). Youth and Political Participation. Rotterdam: Sense Publishers.

Sandel, M. (2011). Justicia. ¿Hacemos lo que debemos? Barcelona: Random House Mondadori.

Scott, J. (2006). The Mission of the University: Medieval to Postmodern transformations. The Journal of Higher Education, 77(1), Winter, 1-39. doi http://dx.doi.org/10.1353/jhe.2006.0007

Stanley, F. (2008). Save the World on Your Own Time. New York: Oxford University Press.

Steiner, G. (2004). The idea of Europe. Tilburg: Uitgeverij Nexus.

Wyattt, J. (1990). Commitment to Higher Education. Seven West European Thinkers on the Essence of the University. Max Horkeimer, Karl Jaspers, F. R. Leavis, John Herny Newman, José Ortega y Gasset, Paul Tillich, Miguel de Unamuno. Buckingham: SHRE and Open University Press. 


\begin{abstract}
About the Authors
Francisco Esteban Bara

franciscoesteban@ub.edu

Lecturer, Department of Theory and History of Education, University of Barcelona (UB), Spain

Francisco Esteban is a lecturer in the Department of Theory and History of Education at the University of Barcelona (UB), Spain. $\mathrm{He}$ is a member of the consolidated Research Group on Moral Education (GREM) at the same university. His lines of research focus on Education in Values and Ethical Education in universities. He has had various articles on these topics published in monographic books and renowned journals. In 2002 he received an award from the Oscense del Voluntariado-UNICEF platform for the essay: Excelentes profesionales y comprometidos ciudadanos: un cambio de mirada desde la universidad.

Departamento de Teoría e Historia de la Educación

Edifici de Llevant, 3 a Planta

Passeig de la Vall d'Hebron, 171

08035 Barcelona, Spain
\end{abstract}

\title{
Teodor Mellen Vinagre
}

teodor.mellen@esade.edu

Lecturer, Department of Social Sciences, ESADE, Spain

Teodor Mellen is a lecturer in the Department of Social Sciences, ESADE, Spain. A sociologist by profession, he works in social research and university teaching. He is a member of the ESADE-URL Observatory of Values. His lines of interest include research methods and techniques, and social and cultural change processes.

Departament de Ciències Socials

ESADE Universitat Ramon Llull

Av. Pedralbes, 60-62

08034 Barcelona, Spain

\section{Maria Rosa Buxarrais Estrada}

mrbuxarrais@ub.edu

University Professor, Department of Theory and History of Education, University of Barcelona (UB), Spain

She is the principal researcher of the consolidated Research Group on Moral Education (GREM) at the University of Barcelona (UB), Spain. Her lines of research are Higher Education and Ethical Learning, Families and Education in Values, among others. She has had articles published in renowned national and international journals.

Departamento de Teoría e Historia de la Educación

Edifici de Llevant, $3^{\text {a }}$ Planta

Passeig de la Vall d'Hebron, 171

08035 Barcelona, Spain

Original title Concepciones del profesorado universitario sobre la formación ética y ciudadana en el Espacio Europeo de Educación Superior: un estudio de caso

The texts published in this journal are - unless indicated otherwise - covered by the Creative Commons Spain Attribution 3.0 licence. You may copy, distribute, transmit and adapt the work, provided you attribute it (authorship, journal name, publisher) in the manner specified by the author(s) or licensor(s). The full text of the licence can be consulted here: <http://creativecommons.org/licenses/by/3.o/es/deed.en>

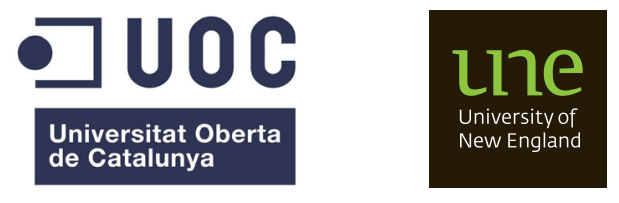

RUSC VOL. 11 No 3 | Universitat Oberta de Catalunya and University of New England | Barcelona, July 2014 